\title{
DETERMINATION OF VITAMIN D IN FISH AND FISH PRODUCTS BY CHROMATOGRAPHY WITH JAPANESE ACID CLAY
}

\author{
HIDEO HIGASHI, TAKESHIGE YAMAKAWA, TOYOSUKE KINUMAKI, \\ KISABURO SUGII AND KIKUKO IWASAKI
}

Tokai Regional Fisheries Rescarch Laboratory, Tsukishima, Kyobashi, Tokyo

(Received June 17, 1961)

Methods so far proposed for physicochemical determination of vitamin D are reliable only when a sample contains impurities such as vitamin A in a relatively small amount, $e . g$. , the prescription of the U.S. Pharmacopeia (1). Although it might be applicable to the determination of medicines containing vitamin $\mathrm{D}$, it can not be used for the determination of fish products which usually accompany vitamin A. In order to secure a method for this purpose we used activated Japanese acid clay (hereafter simply called "the clay") as an adsorbent together with activated alumina. As the method seems to be applicable to the determination of vitamin $\mathrm{D}$ in various forms of fish products at a high level of accuracy, the technique will be described in detail in this paper.

REAGENTS AND APPARATUS

\section{Alumina}

Merck's preparation was used for an adsorbent.

2. Petroleum Ether (PE)

A chemically pure grade preparation of the Nihon Sekiyu Co. was distilled. The main distillate (bp $40-60^{\circ}$ ) was dried over anhydrous sodium sulfate.

3. Ether (E)

A commercial preparation was purified by removing peroxides and dried over anhydrous sodium sulfate, followed by distillation. The main distillate was dried again with the same drying agent.

\section{Chloroform}

A commercial preparation was washed with concentrated $\mathrm{H}_{2} \mathrm{SO}_{4}$, and then with water and $\mathrm{KOH}$ solution. After washing again with water, it was distilled. The main distillate was dried over potassium carbonate overnight. 


\section{Antimony Trichloride}

An extra pure grade preparation of Yotsuhata Kagaku Co. was recrystallized from the purified $\mathrm{CHCl}_{3}$.

\section{Acetyl Chloride}

An extra pure grade preparation of Kanto Kagaku Co. was used.

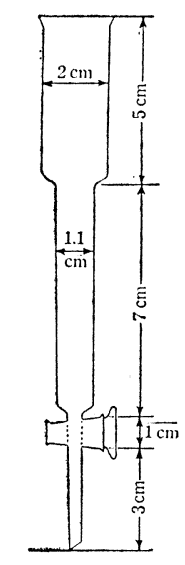

For acid clay chromatography

FI. 1 graphy

Instruments Used for Chromato-

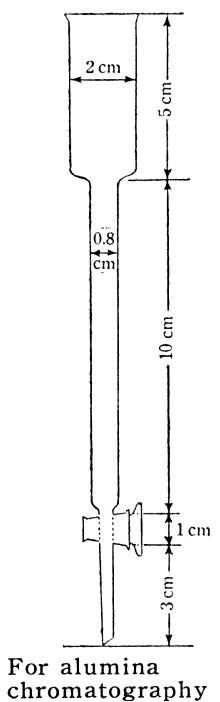

chromatography
Used for Chromato-

diameter of each column was corrected.

7. $\mathrm{SbCl}_{3}$-Acetyl Chloride Reagent

It was prepared by dissolving 200 mg $\mathrm{SbCl}_{3}$ per $\mathrm{ml} \mathrm{CHCl}_{3}$. Acetyl chloride was added before use $(0.4 \mathrm{ml}$ to $20 \mathrm{ml}$ of $\mathrm{SbCl}_{3}$ solution).

8. Vitamin A Alcohol

A preparation of crystalline vitamin A acetate $(2,900,000$ U. S. P. U./g) of the Riken Vitamin Co. was saponified to extract vitamin A alcohol.

9. Vitamin $\mathrm{D}_{2}$

A preparation of the Riken Vitamin Co. was recrystallized from wet acetone to a state showing $E_{1 \mathrm{~cm}}^{1 \%} 265$ $\mathrm{m} \mu=470, \mathrm{mp} 115^{\circ}$, then it was purified by alumina chromatography.

10. Glass Instruments Used for Chromatography

They are shown in Fig. $1 . \quad$ The

RESULTS

Studies on the Clay Activity

Attempts to use the clay for vitamin $\mathrm{D}$ determination have already been made by Baba (2) and Miwa (3). The methods adopted by the authors have not been described in detail for general use and the conditions for activation do not appear to have been investigated thoroughly. In view of securing a standard clay, therefore, we activated the clay under various conditions.

\section{Preparation of the Clay Suitable for Chromatography}

Usually commercial clay is so fine as to prevent rapid filtration and results in a loss of vitamin D even if it is mixed with celite for quickening the filtration. For the purpose of preparing the clay with the particles of suitable size, 10 parts of the commercial clay was kneaded with 7 parts of water and was pushed out in a form of noodle. After drying at $95^{\circ}$ to $100^{\circ}$ until complete evaporation of the water added, the clay was crashed up to the particles of 100 to 150 mesh. The grains were activated at a proper temperature to be mentioned later and kept in a desiccator together with $\mathrm{P}_{2} \mathrm{O}_{5}$ as a 
drying agent.

2. Clay Chromatography

Cotton wool is placed on the bottom of the column. Pour the E-PE mixture $(3: 7, \mathrm{v} / \mathrm{v})$, and then put a suitable amount ${ }^{1}$ of the clay into the column under light agitation with a glass rod up to about $6 \mathrm{~cm}$ in height. Then the stopcock is opened to let the solvent flow down. The sample diluted with the E-PE mixture $(3: 7, \mathrm{v} / \mathrm{v})$ is placed at the top of the column and washed with the same solvent mixture. Use the first $50 \mathrm{ml}$ of the eluate for the determination.
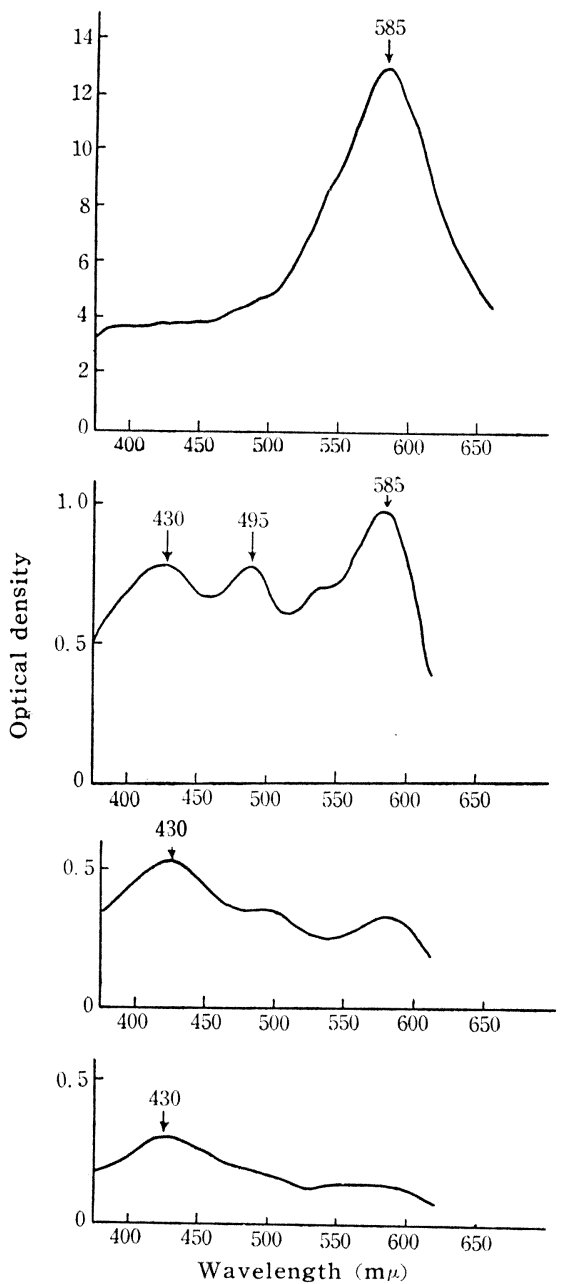

The clay was heated for an hour at $95^{\circ}$.

The clay was heated first for 30 minutes at $95^{\circ}$ and then for 15 minutes at $130^{\circ}$.

The clay was heated first for 30 minutes at $95^{\circ}$ and then for 15 minutes at $150^{\circ}$.

The clay was heated first for 30 minutes at $95^{\circ}$ and then for 30 minutes at $190^{\circ}$.

Fig. 2 Absorption Spectra of the Colored Solution by $\mathrm{SbCl}_{3}$ of Vitamin A Decomposition Products Produced by Chromatography Using the Clay of Varying Activations

1 Until better specified later, $4 \mathrm{~g}$ of the clay was used in the early stages of the experiments. 


\section{Alumina Chromatography}

When alumina is used as an adsorbent, alumina suspended with the E-PE mixture $(1: 9)$ is poured into the tube. Open the stop-cock to let the solvent flow down and the alumina settle down until the column becomes about $11 \mathrm{~cm}$ in height. The sample having passed through the clay chromatography is applied to the column. Three fractions are separately caught using $500 \mathrm{ml}$ each of the solvent mixtures, E-PE mixture $(1: 9, \mathrm{v} / \mathrm{v})$, the same mixture $(3: 7, \mathrm{v} / \mathrm{v})$ and ether, respectively.

\section{Determination of the Color Produced by $\mathrm{SbCl}_{3}$ Reaction}

The residue is dissolved in a certain volume of $\mathrm{CHCl}_{3} ; 0.3 \mathrm{ml}$ of this solution is allowed to react with $3.0 \mathrm{ml}$ of the $\mathrm{SbCl}_{3}$ reagent. After 1 minute the optical density $(500 \mathrm{~m} \mu, 1 \mathrm{~cm})$ of the solution is determined with a spectrophotometer (4).

5. Relation between the Activity of the Clay and the Decomposition Products Derived from Vitamin $A$

The clay adsorbs and decomposes vitamin A during chromatography (5, 6). We found that the vitamin A decomposition products are different depending on the activity of the clay.

When $10 \mathrm{mg}$ of pure vitamin A specified above was applied to the clay chromatography mentioned in 1, some of the vitamin A decomposition products appeared in the eluate, whose absorption spectra after adding the $\mathrm{SbCl}_{3}$ reagent were determined spectrophotometrically as shown in Fig. 2.

The intensity and shape of the absorption spectra of the decomposition products were shown to vary depending on the heating condition of the clay. When the clay activated by heating at $95^{\circ}$ to $100^{\circ}$ was used, the main absorption maximum of the color exsists at $585 \mathrm{~m} \mu$, the intensity being very

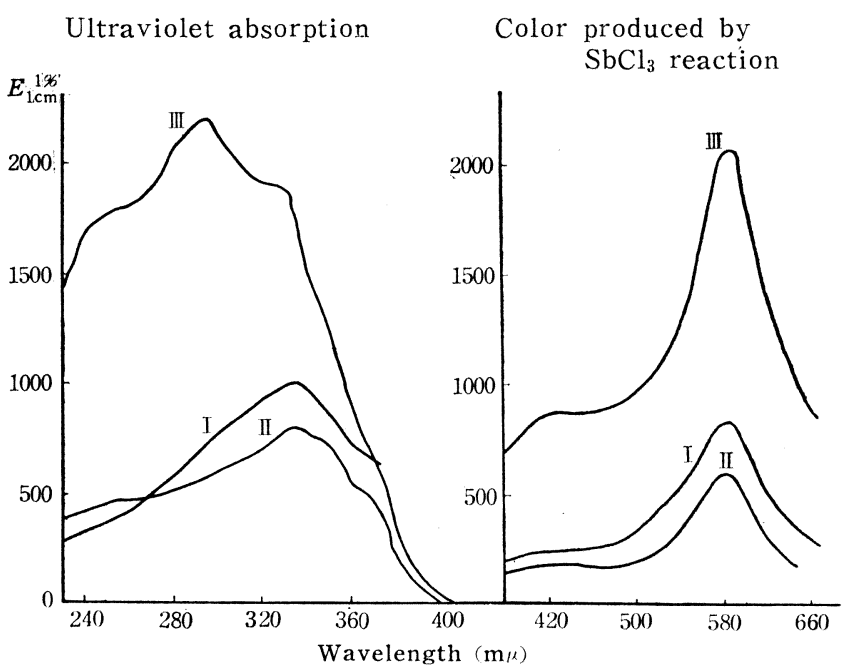

FIta. 3 Absorption Spectra of the Fractions Obtained by Alumina Chromatography of Vitamin A Decomposition Products through the Clay Heated at $95-100^{\circ}$ 
strong. However, in the case of the clay heated at $190^{\circ}$, the main maximum appeared at $430 \mathrm{~m} \mu$, the intensity being very weak. The vitamin A decomposition products, showing the main absorption maximum at 585 and $430 \mathrm{~m} \mu$, respectively, under the condition mentioned above are hereafter called " 585

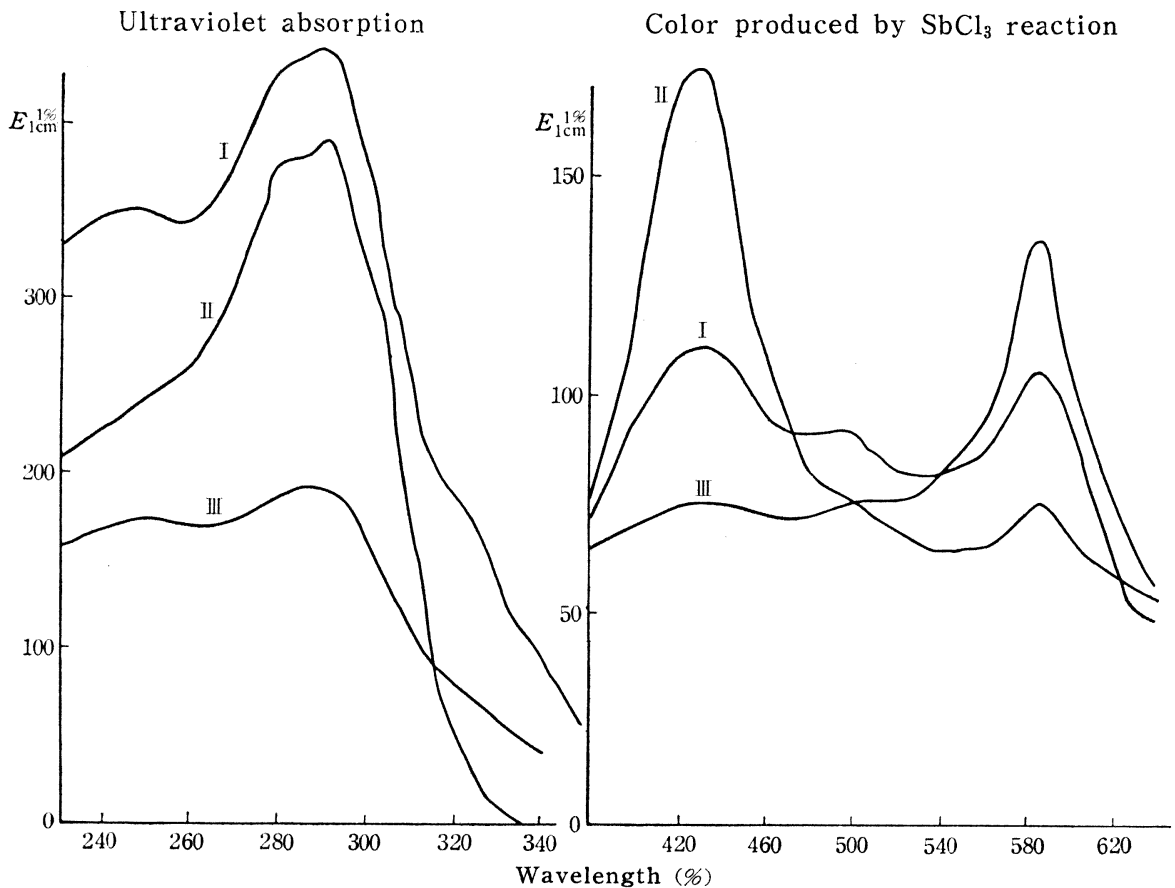

Fis. 4 Absorption Spectra of the Fractions Obtained by Alumina Chromatography of Vitamin A Decomposition Products through the Clay Heated at $150^{\circ}$

TABLE I

Alumina Chromatography of Vitamin A Decomposition Products through the Clay Heated at $95^{\circ}$ to $100^{\circ}$

\begin{tabular}{ccccccc}
\hline Fraction no. & $\begin{array}{l}\text { Solvent } \\
\text { used }\end{array}$ & Weight $\begin{array}{l}\text { Absorption } \\
\text { maximum } \\
\text { of colored } \\
\text { solution }\end{array}$ & $E_{1 \mathrm{~cm}}^{1 \%} 585 \mathrm{~m} \mu$ & $\begin{array}{l}\text { Absorption } \\
\text { maxima in } \\
\text { ultraviolet } \\
\text { region } a\end{array}$ & Solubility \\
$\begin{array}{c}\text { Before } \\
\text { chromatography }\end{array}$ & $\%$ & $m \mu$ & & $m \mu$ & \\
I & $\begin{array}{c}\text { E-PE } \\
(1: 9)\end{array}$ & 30 & 585 & 831 & 335,370 & $\begin{array}{l}\text { Sparingly } \\
\text { soluble in } \\
\text { alcohol }\end{array}$ \\
II & $\begin{array}{l}\text { E-PE } \\
(3: 7)\end{array}$ & 19 & 585 & 601 & $\begin{array}{l}335,350 \\
370,260\end{array}$ & $\begin{array}{l}\text { Sparingly } \\
\text { soluble in } \\
\text { alcohol }\end{array}$ \\
III & E & 4 & 585 & 2,060 & $\begin{array}{l}293.5,330, \\
255\end{array}$ & $\begin{array}{l}\text { Soluble in } \\
\text { alcohol }\end{array}$
\end{tabular}

${ }^{a}$ Arranged in the order of absorption intensity, with inflections shown in italics throughout Tables I to IV. 
and 430 chromogen". From this result, the decomposition products seem to differ each other according to the activity of the clay. To assure this point, these decomposition products were divided into several fractions using the alumina chromatography mentioned in 3 and their properties were compared with the results shown in Tables I to IV as well as Figs. 3 and 4 . Comparison of these results with Fig. 2 shows that the 585 chromogen obtained from the clay of weak activity (Fraction I in Tables I and III and Fig. 3) is different from the 430 chromogen separated by the clay of stronger activity (Fr. II in Table II and IV, Fig. 4) in chromatographic behavior and ultraviolet absorption.

TABLE II

Alumina Chromatography of Vitamin A Decomposition Products through the Clay Heated at $150^{\circ}$

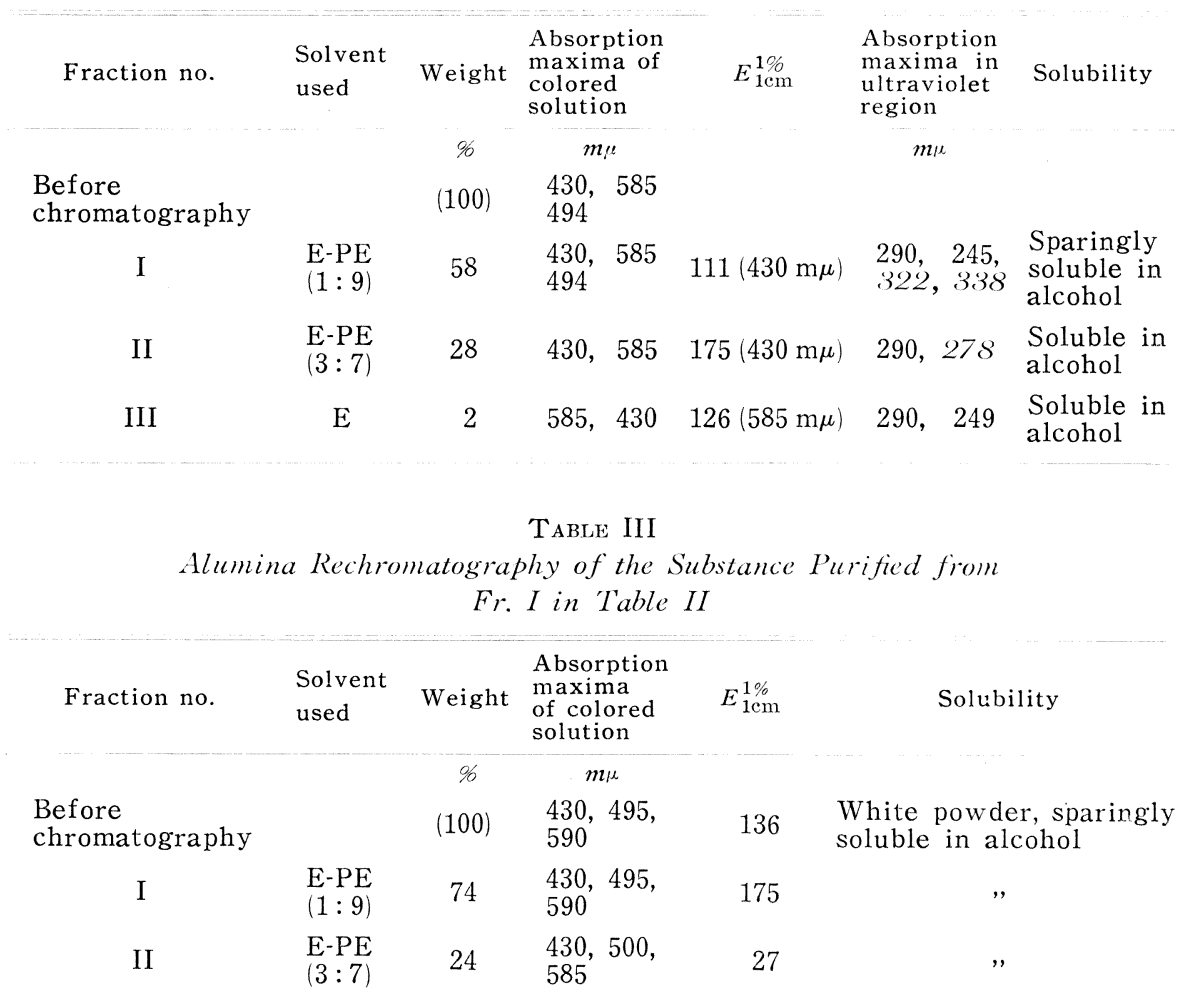

\section{Vitamin D Recovery in the Clay Chromatography}

The complicated feature of vitamin A decomposition products was shown in the foregoing observations. The clay to be used for vitamin D determination should adsorb vitamin A decomposition products as much as possible without destroying vitamin $\mathrm{D}$.

The recovery test of $20 \mu \mathrm{g}$ vitamin $\mathrm{D}$ in the clay chromatography has 
TABLE IV

Alumina Rechromatography of the Substances Purified from

Fr. II in Table II

\begin{tabular}{|c|c|c|c|c|c|}
\hline Fraction no. & $\begin{array}{l}\text { Solvent } \\
\text { used }\end{array}$ & Weight & $\begin{array}{l}\text { Absorption } \\
\text { maxima } \\
\text { of colored } \\
\text { solution }\end{array}$ & $E_{1 \mathrm{~cm}}^{1 \%} 430 \mathrm{~m} \mu$ & Solubility \\
\hline & & $\%$ & $m \mu$ & & \\
\hline $\begin{array}{l}\text { Before } \\
\text { chromatography }\end{array}$ & & $(100)$ & 430,585 & 403 & Soluble in alcohol \\
\hline I & $\begin{array}{l}\text { E-PE } \\
(1: 9)\end{array}$ & 28 & $\begin{array}{l}430,585 \\
500\end{array}$ & 378 & $\begin{array}{l}\text { Practically soluble in } \\
\text { alcohol }\end{array}$ \\
\hline II & $\begin{array}{l}\mathrm{E}-\mathrm{PE} \\
(3: 7)\end{array}$ & 64 & 430,585 & 307 & Soluble in alcohol \\
\hline
\end{tabular}

proved that only the clay heated at $95^{\circ}$ to $100^{\circ}$ can be used for vitamin $\mathrm{D}$ determination, whereas those heated at higher temperatures $\left(130^{\circ}\right.$ to $\left.190^{\circ}\right)$ promote 430 chromogen formation, lowering the recovery rate unsuitably as shown in Table V.

TABLE V

Recovery Test of Vitamin D Using the Clay Heated under Various Conditions

$\begin{array}{lc}\text { Heating conditions for activating acid clay } & \text { Recovery } \\ \text { One hour, } 95^{\circ} & \% \\ 30 \text { minutes, } 95^{\circ} ; 15 \text { minutes, } 130^{\circ} & 50 \\ 30 \text { minutes, } 95^{\circ} ; 15 \text { minutes, } 150^{\circ} & 34 \\ 30 \text { minutes, } 95^{\circ} ; 15 \text { minutes, } 190^{\circ} & 0\end{array}$

\section{Conditions for Activating the Clay}

If the heating time of the clay is too long even at the temperature below $100^{\circ}$, the recovery sometimes becomes low. Furthermore, the heating time has an effect on the quantity of 585 chromogen appearing in the vitamin D fraction, which has to be kept at a minimum. With this point in mind, the conditions for preparing the clay suitable for chromatography were investigated.

Optimal Amount of Water for Preparing Granular Clay - In recovery tests to determine an optimal quantity of water needed for preparing granular clay, the clay mixed with 50 or 70 parts of water was heated until it gained its initial weight. Then heating was continued for either 2 or 4 hours more. From Table VI showing the vitamin D recovery through each of these clays, it can be seen that with 50 parts of water the same duration of heating was necessary for about the same recoveries of vitamin D as well as appearance of 585 chromogen. 
TABLE VI

Conditions for Producing Granular Acid Clay

$\begin{array}{cccc}\begin{array}{l}\text { Volume of } \\ \text { water added }\end{array} & \text { Heating time } & \begin{array}{l}\text { Vitamin D } \\ \text { recovery }\end{array} & \begin{array}{l}\text { Extinction value of } \\ 585 \text { chromogen }\end{array} \\ 9 \% & h r & \% & \\ 50 & 8 & 100 & 71.5 \\ 50 & 10 & 82 & 31.9 \\ 50 & 14 & 85 & 22.5 \\ 70 & 9 & 100 & 40.7 \\ 70 & 11 & 100 & 44.0 \\ 70 & 15 & 100 & 22.0\end{array}$

Optimal Length of Heating Time for Activation- Granular clay $25 \mathrm{~g}$, prepared from the clay mixed with 70 parts of water was placed in a Petri dish, $6 \mathrm{~cm}$ in diameter. In the present test, the layer of the clay was made comparatively thin. Prior to desiccation, one of the clay samples thus prepared was not heated; other samples were heated for 2, 4, 6 and 8 hours, respectively; all of them were then desiccated over $\mathrm{P}_{2} \mathrm{O}_{5}$ for 16 hours. Using these clay samples, vitamins $\mathrm{A}$ and $\mathrm{D}$ were subjected to chromatography to determine the recovery of vitamin $\mathrm{D}$ and the quantity of 585 chromogen (Fig. 5). The results indicate:

(a) The quantity of 585 chromogen is roughly inversely proportional to the weight loss of the clay by heating, probably representing the quantity of

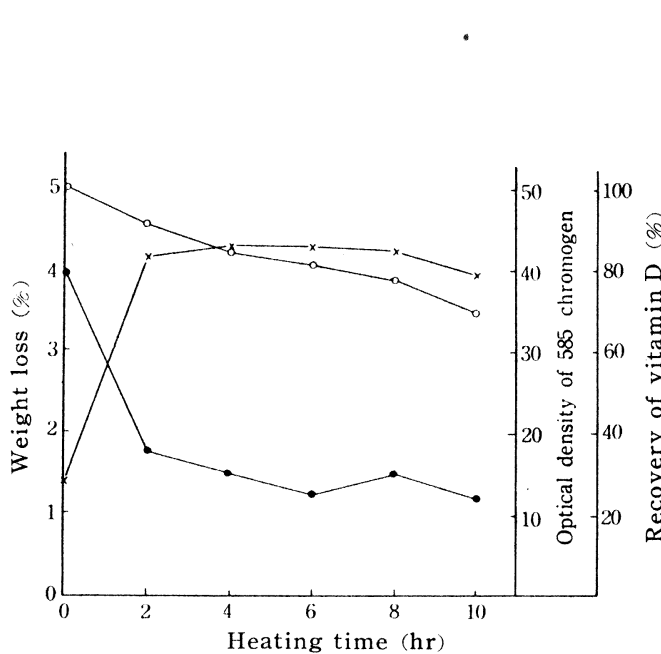

FI(i. 5 Relationships among Weight Loss of Granular Acid Clay, Quantity of 585 Chromogen and Recovery of Vitamin D, When the Clay Activated in a Thin Layer was Used

$x$, weight loss; 0 , recovery of vitamin

D; $\bullet 585$ chromogen.

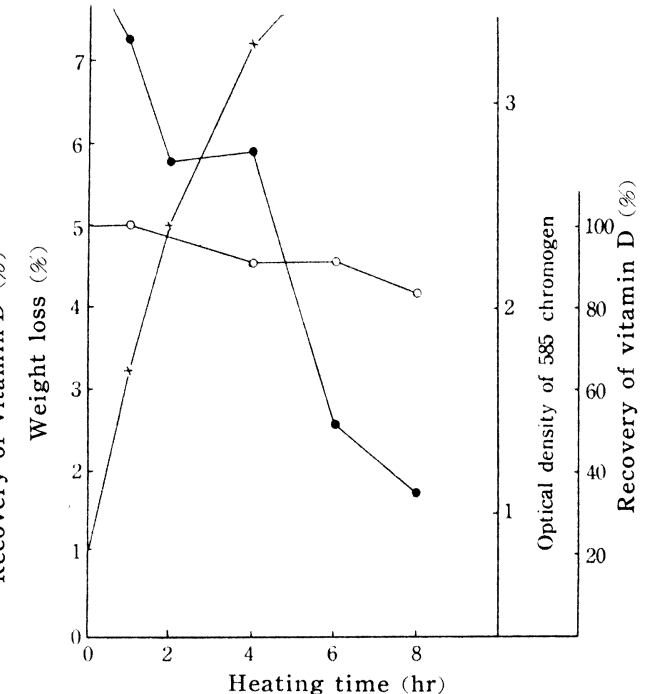

Fig. 6 Relationships among Weight Loss of Granular Acid Clay, Quantity of 585 Chromogen and Recovery of Vitamin D, When the Clay Activated in a Thick Layer was Used

$\times$, weight loss ; $O$, recovery of vitamin $\mathrm{D} ; \bullet, 585$ chromogen. 
water in the caly; (b) the vitamin D recovery, independent of the weight loss on heating, lowers with the progress of heating after the first 2 hours; (c) Heating the clay for more than 2 hours should be avoided. The use of a thin layer of the clay as in these experiments is not practical. Therefore in the following experiments, the clay layer, about $3 \mathrm{~cm}$ in thickness, was used (Fig. 6). Although the weight loss in these experiments occurred later than in the thin layer, other behaviors were roughly the same as in the experiments shown in Fig. 5 .

Relation between the Desiccating Period and Formation of 585 Chromogen

The fact that the quantity of 585 chromogen formed was roughly inversely proportional to the weight loss of the clay suggests a possibility of reducing the quantity of 585 chromogen without affecting the vitamin D recovery using the clay desiccated for a long time. The experiments on chromatography along this line proved the idea to be valid as shown in Table VII.

TABLE VII

Correlation between Desiccating Periods and Formation of 585 Chromogen

\begin{tabular}{ccc} 
Desiccating periods & $\begin{array}{l}\text { Extinction value of } \\
585 \text { chromogen }\end{array}$ & Vitamin D recovery \\
\hline day & 33.0 & $\%$ \\
1 & 9.3 & 100 \\
4 & & 100
\end{tabular}

Relation between the Quantity of Clay and Formation of 585 Chromogen

Now that the method to prepare the clay suitable for chromatography has been secured, the second step was tried to reduce the formation of 585 chromogen by increasing the quantity of the clay used. It was found that an increase of the clay from 4 to $6 \mathrm{~g}$ resulted in the decrease in chromogen formation to some extent without affecting the vitamin $\mathrm{D}$ recovery (Table VIII). For this reason it is expected that a sample which is supposed to contain much greater amounts of vitamin A and impurities other than vitamin $\mathrm{D}$ can be subjected to vitamin $\mathrm{D}$ determination by increasing the quantity of the clay.

TABLE VIII

Correlation between Weight of Acid Clay and Formation of 585 Chromogen

$\begin{array}{cccc}\begin{array}{c}\text { Weight of } \\ \text { acid clay }\end{array} & \begin{array}{c}\text { Extinction value of } \\ 585 \text { chromogen }\end{array} & \begin{array}{l}\text { Vitamin D } \\ \text { recovery }\end{array} & \begin{array}{c}\text { Volume of } \\ \text { solvent }\end{array} \\ g & & \% & m l \\ 4 & 46.0 & 100 & 50 \\ 6 & 22.0 & 97 & 50 \\ 8 & 14.4 & 92 & 60\end{array}$

Various Brands of the Clay In all the experiments described above, the 
clay supplied by the Mizusawa Kagaku Kogyo Co., Ltd. was used. We examined, therefore, whether or not other products from different localities or batches would give the same results. Of the three samples of the clay examined for this purpose, the batches $a$ and $b$ from the Mizusawa Kogyo and another from a second company were all found useful (Table IX).

TABLE IX

The Chromatography of Vitamins $A$ and $D$ Using Various Brands of the Clay

$\begin{array}{cccc}\text { Producer } & \begin{array}{c}\text { Place of production } \\ \text { (Prefecture) }\end{array} & \begin{array}{c}\text { Extinction value } \\ \text { of 585 chromogen }\end{array} & \begin{array}{c}\text { Vitamin D } \\ \text { recovery }\end{array} \\ \begin{array}{c}\text { Mizusawa Kagaku Kogyo } \\ \text { Co., Ltd. }(a)\end{array} & \text { Yamagata } & 50.0 & 97 \\ \begin{array}{c}\text { Mizusawa Kagaku Kogyo } \\ \text { Co., Ltd. }(b)\end{array} & \text { Yamagata } & 63.5 & 100 \\ \begin{array}{c}\text { Nihon Kassei Hakudo } \\ \text { Co., Ltd. }\end{array} & \text { Niigata } & 62.4 & 100\end{array}$

Separation of Vitamin D and Vitamin A Decomposition Products with Gradient Alumina Chromatography Since a little amount of 585 chromogen still appeared in the vitamin D fraction even after clay chromatography, it seemed necessary to separate the chromogen and vitamin $\mathrm{D}$ before measurement of the color of $\mathrm{SbCl}_{3}$ reaction.

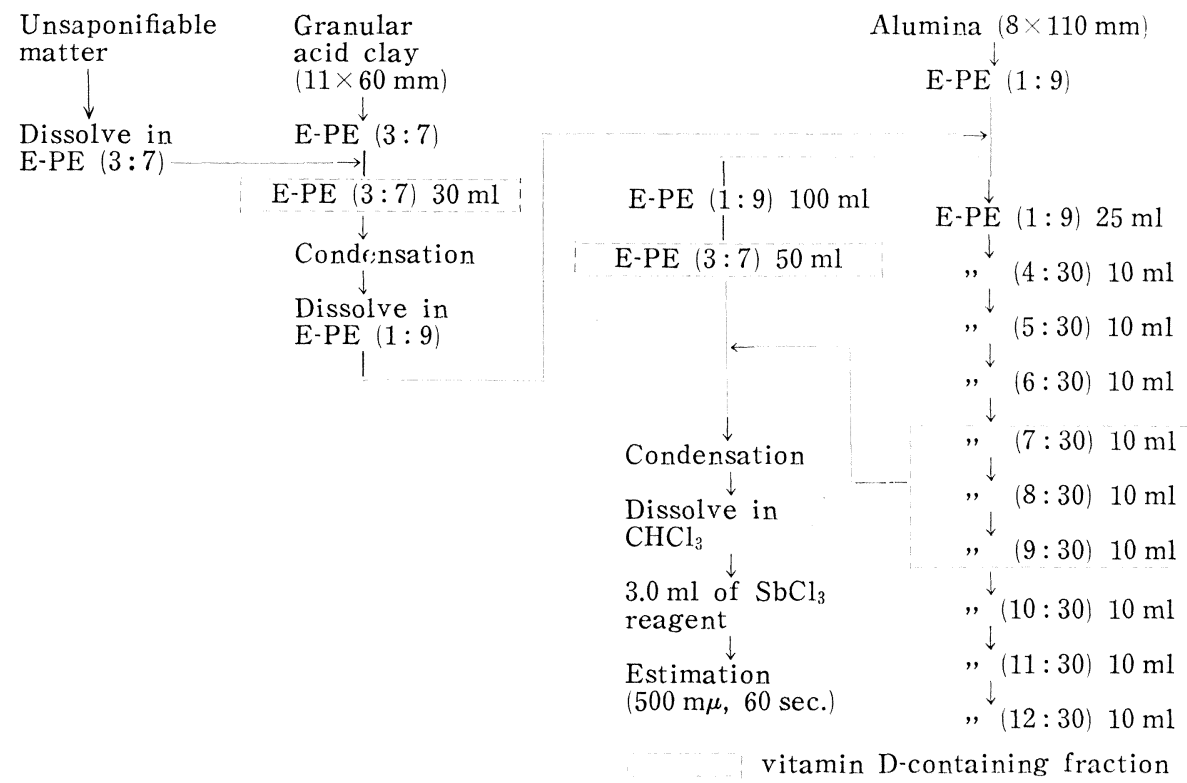

Fig. 7 Schematic Outline of Vitamin D Determination 
In accordance with Plack's method (7), 585 chromogen derived from vitamin $\mathrm{A}$ in the clay chromatography and $50 \mu \mathrm{g}$ of vitamin $\mathrm{D}_{2}$ were separated using gradient alumina chromatography. The method of elution is to obtain the first fraction with $25 \mathrm{ml}$ of E-PE mixture $(1: 9)$ and each of the further fractions with 10 $\mathrm{ml}$ of the same mixture, whereby the polarity was gradually strengthened one after another (Fig. 7). The elution curve of gradient alumina chromatography reveals that 585 chromogen produced from vitamin $A$ is divided into three groups (Fig. 8).

Then, using the sample containing $10 \mathrm{mg}$ vitamin A and $20 \mu \mathrm{g}$ vitamin D, it was tested to see if the separation of the vitamins was possible by combining the clay and gradient alumina chromatography. A satisfactory result was thus obtained, the recovery of vitamin D during the procedure being practically perfect.

In our experiment vitamin $\mathrm{D}$ appears in the fractions 7 to 9 which can be applied to the determination, though the fraction may occasionally slip according to the activity of alumina.

Separation of Unsaponifiable Components Other than Vitamins A and D The separation of vitamins A and D was described above. However, samples to be treated may contain various unsaponfiable components other than vitamin $\mathrm{A}$ and $\mathrm{D}$. The color produced by $\mathrm{SbCl}_{3}$ reaction of these components and the methods of separation were therefore investigated. Fig. 9 shows the absorption spectra of the $\mathrm{SbCl}_{3}$-color of fairly pure specimens of oleyl, selachyl, and batyl alcohol and cholesterol.

Comparing with the intensity of $\mathrm{SbCl}_{3}$-color of vitamin $\mathrm{D}$, those of the former three alcohols are so weak that we can neglect their effects, even when they appear in the vitamin D fraction. Though cholesterol produces a color of significantly stronger intensity, it can be easily removed from the samples by low temperature crystallization or digitonin treatment.

Besides these alcohols was found in the course of experiments a steroid which increased $\mathrm{SbCl}_{3}$-color with the progress of time, thus disturbing vitamin $\mathrm{D}$ determination. This steroid appears in the vitamin $\mathrm{D}$ fraction even after the combined clay and gradient alumina chromatography. Moreover, it cannot be completely separated by low temperature precipitation. It forms, 


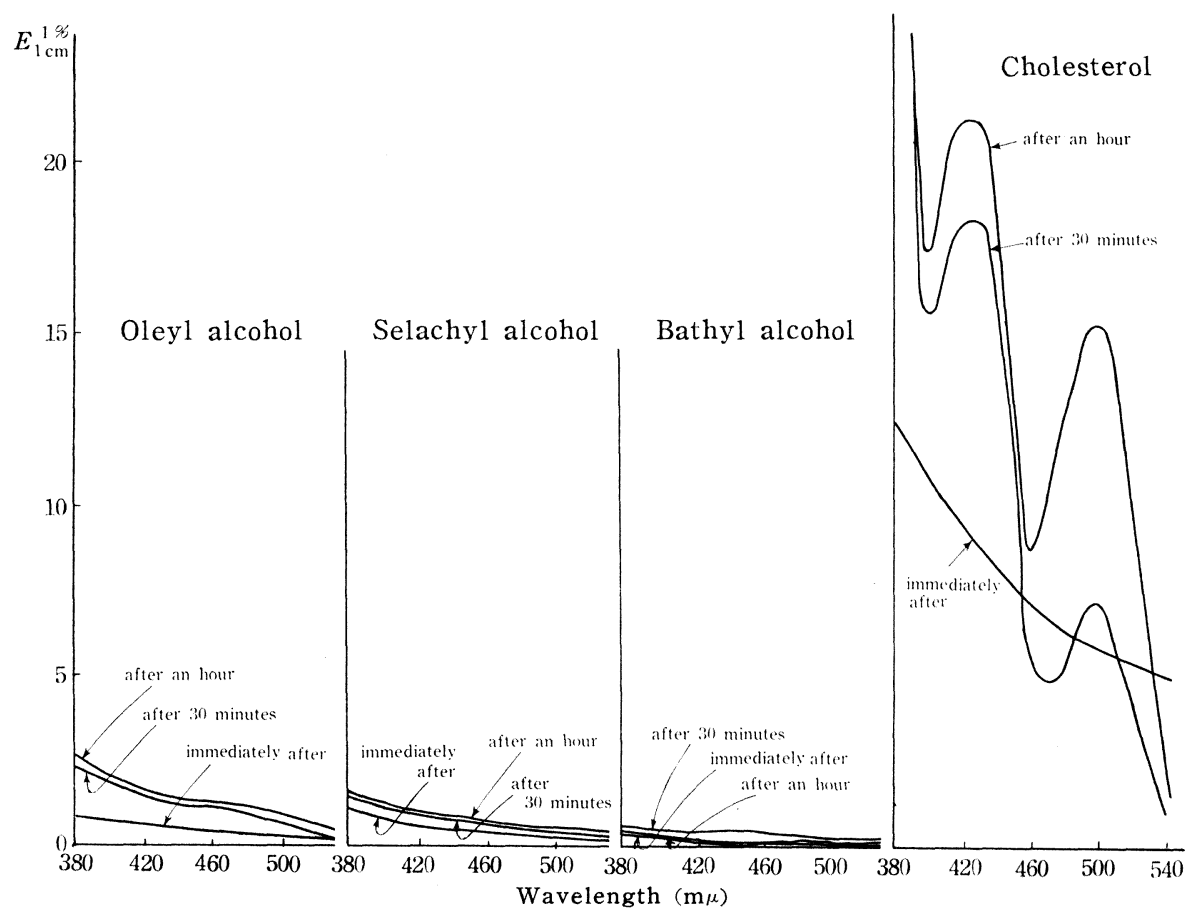

Fia. 9 Absorption Spectra of Colored Solutions of Oleyl Selachyl, Batyl Alcohol and Cholesterol by $\mathrm{SbCl}_{3}$ Reagent

however, digitonide and after digitonin treatment the intensity of $\mathrm{SbCl}_{3}$-color becomes zero within the whole range of wavelengths from 340 to $600 \mathrm{~m} \mu$. Other unsaponifiable components, occurring often in the course of vitamin D determination of fish and fish products can be removed by the combined clay and alumina chromatography.

\section{Proposed Method of Determination}

\section{Preparation of Samples}

Saponification and Extraction-Saponify 1 to $10 \mathrm{~g}^{1}$ of the oil extracted from fish or fish products with methanolic $\mathrm{KOH}$ solution and extract the unsaponifiable matter several times with ether specified above.

Methanol Treatment Cool the methanol solution of the unsaponifiable matter in a refrigerator, and remove the precipitates by filtration.

Digitonin Treatment-Dissolve in $2 \mathrm{ml}$ of $80 \%$ ethanol the residue obtained by evaporating the filtrate. Add 1 or $2 \mathrm{ml}$ of digitonin solution (30 $\mathrm{mg}$ per $1 \mathrm{ml}$ of $80 \%$ ethanol), warm the mixture with stirring and allow to stand for an hour. Filter the mixture into a test tube to separate the digitonide. Wash the digitonide with $1 \mathrm{ml}$ of $80 \%$ ethanol and then with $4 \mathrm{ml}$

1 Although the weight of the oil is to be determined according to the potency of vitamin $A$, the total amount of vitamin $A$ in the oil must not exceed 33,000 I.U. 
of PE. Shake and let the filtrate settle to transfer the upper layer to another test tube. Repeat the extraction of the lower layer 4 times using $4 \mathrm{ml}$ each of PE. Wash the combined extract with $3 \mathrm{ml}$ of water, place the extract in a flask and remove the solvent completely under reduced pressure.

2. Clay and Alumina Chromatography

Apply the sample thus prepared to the clay and gradient alumina chromatography. In the case of the sample containing very little impurities, alumina chromatography can be simplified as follows. After washing the alumina column with $100 \mathrm{ml}$ of E-PE mixture $(1: 9), 50 \mathrm{ml}$ of the eluate with E-PE mixture $(3: 7)$ is taken as vitamin $\mathrm{D}$ fraction.

\section{Determination and Calculation}

Vitamin D determination is carried out as described above. The content (I. U. per g) is calculated by the following formula :

$$
\text { Vitamin D content }=\frac{R \times k \times d \times 40}{w}
$$

where $R=$ optical density, $k=$ conversion factor, which is determined from the standard solution of vitamin $\mathrm{D}_{2}$, $d=$ volume of $\mathrm{CHCl}_{3}$ for dilution, $w=$ weight of the sample used $(\mathrm{g})$.

Examples of Vitamin D Determination by the Proposed Method -. Vitamin $\mathrm{D}$ contents in fish and fish products determined by the present method are shown in Tables X to XII. Though scarcity of the available data makes it difficult to generalize the results, the following might be noticed. (a) Vitamin D contents vary depending on the part of the body as well as species. In one group of fish such as mackerel, bluefin tuna, yellowtail, and Japanese flounder, vitamin D exists mainly in the liver but little in other organs. On the other hand, in the sardine vitamin D occurs both in the flesh and the wastes including the head and bones at a fairly high level, comparable with the level of the viscera. Another group, such as horse mackerel and flatfish, contains little or no detectable amount of vitamin D in the flesh and viscera (Table X). (b) Among the commercial products tested for the applicability of the method, it is interesting to note that vitamin D, which is un- 
TABLE X

Vitamin D Contents in Various Fishes

\begin{tabular}{|c|c|c|c|c|c|c|c|}
\hline \multirow{3}{*}{$\begin{array}{l}\text { Common and } \\
\text { scientific name }\end{array}$} & \multirow{3}{*}{ Part of fish } & \multirow{3}{*}{$=\frac{\stackrel{ \pm}{ \pm}}{\sigma}$} & \multirow{2}{*}{\multicolumn{2}{|c|}{$\begin{array}{l}\text { Vitamin A, } \\
\text { I.V. per }\end{array}$}} & \multirow{2}{*}{\multicolumn{2}{|c|}{$\begin{array}{l}\text { Vitamin D, } \\
\text { I.I. per }\end{array}$}} & \multirow{3}{*}{$\begin{array}{l}\text { A } / \text { D } \\
(\text { I.U. })\end{array}$} \\
\hline & & & & & & & \\
\hline & & & $\begin{array}{l}\lg \text { of } \\
\text { oil }\end{array}$ & $\begin{array}{l}00 \mathrm{~g} \text { of } \\
\text { tissue }\end{array}$ & $\begin{array}{l}1 \mathrm{~g} \text { of } \\
\text { oil }\end{array}$ & $\begin{array}{l}100 \mathrm{~g} \text { of } \\
\text { tissue }\end{array}$ & \\
\hline & & $\%$ & & & & & \\
\hline $\begin{array}{c}\text { Sardine } \\
\text { Sardinops melanosticta }\end{array}$ & $\begin{array}{l}\text { Flesh } \\
\text { Viscera } \\
\text { Waste }\end{array}$ & $\begin{array}{l}6.4 \\
8.4 \\
7.2\end{array}$ & $\begin{array}{r}13 \\
114 \\
10\end{array}$ & $\begin{array}{r}83 \\
946 \\
72\end{array}$ & $\begin{array}{r}83 \\
71 \\
137\end{array}$ & $\begin{array}{l}532 \\
590 \\
9: 30\end{array}$ & $\begin{array}{l}0.2 \\
1.6 \\
0.1\end{array}$ \\
\hline $\begin{array}{l}\text { Horse mackerel } \\
\text { Trachurus trachurus }\end{array}$ & $\begin{array}{l}\text { Flesh } \\
\text { Viscera } \\
\text { Waste }\end{array}$ & $\begin{array}{r}2.8 \\
12.6 \\
5.7\end{array}$ & $\frac{4}{-}$ & $\frac{11}{-}$ & $\begin{array}{r}\ldots \\
134 \\
\ldots\end{array}$ & $\begin{array}{r}\ldots \\
1,695 \\
\ldots\end{array}$ & \\
\hline $\begin{array}{c}\text { Mackerel } \\
\text { Scomber japonicus }\end{array}$ & $\begin{array}{l}\text { Flesh (with } \\
\text { skin) } \\
\text { Skin } \\
\text { Liver }\end{array}$ & $\begin{array}{l}23.8 \\
17.2 \\
13.3\end{array}$ & $\begin{array}{r}3 \\
9 \\
28,600\end{array}$ & $\begin{array}{r}72 \\
16 \\
380,000\end{array}$ & $\begin{array}{r}6 \\
32 \\
435\end{array}$ & $\begin{array}{r}143 \\
55 \\
5,780\end{array}$ & $\begin{array}{l}0.5 \\
0.3 \\
66\end{array}$ \\
\hline $\begin{array}{l}\text { Bluefin tuna } \\
\text { Thunnus thynnus }\end{array}$ & Liver & 6.7 & 8,480 & 56,700 & 7,800 & 52,200 & 1.1 \\
\hline $\begin{array}{l}\text { Yellowtail } \\
\text { Seriola quinqueradiata }\end{array}$ & $\begin{array}{l}\text { Flesh } \\
\text { Liver } \\
\text { Pyloric caeca } \\
\text { Viscera } \\
\text { Roe } \\
\text { Eye } \\
\text { Head (with- } \\
\text { out eye) }\end{array}$ & $\begin{array}{r}11.8 \\
18.3 \\
51.7 \\
12.2 \\
3.2 \\
23.7 \\
\\
11.8\end{array}$ & $\begin{array}{r}-\overline{1} \\
15,200 \\
395 \\
38 \\
1,710 \\
122\end{array}$ & $\begin{array}{r}- \\
278,000 \\
20,400 \\
460 \\
5,430 \\
2,890\end{array}$ & $\begin{array}{r}\ldots \\
7,450 \\
16 \\
22 \\
\ldots \\
\cdots \\
\\
57\end{array}$ & $\begin{array}{r}\ldots \\
136,300 \\
830 \\
270 \\
\cdots \\
\cdots \\
668\end{array}$ & $\begin{array}{l}20 \\
25 \\
1.7\end{array}$ \\
\hline Young yellowtail & $\begin{array}{l}\text { Dorsal flesh } \\
\text { Ventral flesh } \\
\text { Liver } \\
\text { Pyloric caeca } \\
\text { Kidney } \\
\text { Viscera } \\
\text { Waste }\end{array}$ & $\begin{array}{r}6.6 \\
8.1 \\
9.3 \\
12.5 \\
4.2 \\
3.8 \\
13.3\end{array}$ & $\begin{array}{r}\cdots \\
\ldots \\
1,470 \\
4,230 \\
684 \\
624 \\
\cdots\end{array}$ & $\begin{array}{r}\ldots \\
\ldots \\
13,600 \\
52,900 \\
2,570 \\
2,600 \\
\ldots\end{array}$ & $\begin{array}{r}\ldots \\
7 \\
636 \\
12 \\
\cdots \\
\ldots \\
47\end{array}$ & $\begin{array}{r}\ldots \\
53 \\
5,880 \\
150 \\
\ldots \\
\ldots \\
630\end{array}$ & $\begin{array}{ll}2.3 \\
350\end{array}$ \\
\hline $\begin{array}{c}\text { Flatfish } \\
\text { Pleuronichthys cornutus }\end{array}$ & $\begin{array}{l}\text { Flesh } \\
\text { Viscera } \\
\text { Waste (with- } \\
\text { out milt and } \\
\text { liver) }\end{array}$ & $\begin{array}{l}2.5 \\
1.7\end{array}$ & 29 & $\frac{73}{-}$ & $\begin{array}{l}24 \\
68\end{array}$ & $\begin{array}{r}60 \\
116\end{array}$ & 1.2 \\
\hline $\begin{array}{c}\text { Japanese flounder } \\
\text { Paralichthys olivaceus }\end{array}$ & $\begin{array}{l}\text { Flesh } \\
\text { Liver } \\
\text { Roe } \\
\text { Viscera }\end{array}$ & $\begin{array}{l}0.2 \\
1.4 \\
2.1 \\
1.2\end{array}$ & $\begin{array}{r}\ldots \\
569 \\
\ldots \\
3,080\end{array}$ & $\begin{array}{r}\ldots \\
787 \\
\ldots \\
3,700\end{array}$ & $\begin{array}{r}222 \\
3,100 \\
90 \\
600\end{array}$ & $\begin{array}{r}43 \\
4,200 \\
193 \\
720\end{array}$ & $\begin{array}{l}0.2 \\
5.1\end{array}$ \\
\hline
\end{tabular}

-, no data; $\cdots$, no vitamin detected.

The same are applicable to the following Tables.

stable against exposition to sunlight, still remained in the dried mackerel. It was detected even in fish solubles as well (Table XI). (c) The amount of vitamin $\mathrm{D}$ in shark liver oil is so small that it will possibly be decomposed and become undetectable when the oil is subjected to distillation (Table XII). (d) No correlation exists between the contents of vitamins A and D in most cases regardless of the species or anatomical part of fish, suggesting that 
TABLE XI

Vitamin D Contents in Various Fish Products

\begin{tabular}{|c|c|c|c|c|c|c|c|}
\hline \multirow{2}{*}{ Sample } & \multirow{2}{*}{$\begin{array}{l}\text { Part of fish } \\
\text { product }\end{array}$} & \multirow{2}{*}{ 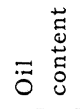 } & \multicolumn{2}{|c|}{ Vitamin A, I.U. per } & \multicolumn{2}{|c|}{ Vitamin $D$, I.V. per } & \multirow{2}{*}{$\begin{array}{l}\text { A/D } \\
(\text { I.V. })\end{array}$} \\
\hline & & & $\begin{array}{l}1 \mathrm{~g} \text { of } \\
\text { oil }\end{array}$ & $\begin{array}{l}100 \mathrm{~g} \text { of } \\
\text { sample }\end{array}$ & $\begin{array}{l}1 \mathrm{~g} \text { of } \\
\text { oil }\end{array}$ & $\begin{array}{l}100 \mathrm{~g} \text { of } \\
\text { sample }\end{array}$ & \\
\hline \multirow{5}{*}{$\begin{array}{l}\text { Dried mackerel } \\
\text { Fish soluble } \\
\begin{array}{c}\text { (N. Co. }) \\
\text { (T. Co.) }\end{array}\end{array}$} & \multirow{5}{*}{$\begin{array}{l}\text { Flesh } \\
\text { Waste }\end{array}$} & $\%$ & & & & & \\
\hline & & 27.4 & 2 & 55 & 9 & 247 & 0.2 \\
\hline & & 14.4 & & 110 & 19 & 270 & 0.4 \\
\hline & & 8.4 & 965 & 8,100 & 431 & 3,620 & 2.2 \\
\hline & & 10.0 & 7,180 & 71,800 & 750 & 7,500 & 9.6 \\
\hline
\end{tabular}

TABLE XII

Vitamin D Contents in Various Vitamin Oils

\begin{tabular}{lccc}
\multicolumn{1}{c}{ Sample } & Vitamin A & Vitamin D & $\begin{array}{c}\text { Vitamin A/Vita- } \\
\text { min D }\end{array}$ \\
& I.v./g & I.U./g & I.U. \\
Mixed shark liver oil distilled & 89,700 & $\ldots$ & 85 \\
Rockfish liver oil & 83,000 & 978 & 11 \\
Swordfish liver oil distilled & 79,100 & 6,930 & 84 \\
Dogfish liver oil distilled & 94,700 & 67 & \\
Great blue shark liver oil & 5,600 & $\ldots$ &
\end{tabular}

the mechanisms of accumulating these two vitamins in the body of fish are different from each other.

\section{DISCUSSION}

Many methods of physicochemical determination of vitamin D proposed up to the present seem to be successful only when they are applied to pharmaceutical preparations $(8,9,10,11,12,13,14)$. In cases of vitamin $\mathrm{D}$ contained in food, they do not secure a reliable result. A few methods reported as applicable to fish products can be applied only to liver oils containing a fairly large amount of vitamin $\mathrm{D}(3,15,16,17)$. By the use of the present method, however, vitamin D seems to be successfully determined in dried products and fish solubles as well as in fish body as given above. Nevertheless, the present method can not be said free from any defects. For instance, when the method is applied to fish roes, it sometimes happens that a small amount of the chromogen having a main absorption maximum at $480 \mathrm{~m} \mu$ appears in the vitamin $\mathrm{D}$ fraction, thus making the correct determination impossible unless the amount of vitamin $\mathrm{D}$ in a sample is large enough. In some samples obtained from the liver of fish such as young yellowtail, another chromogen having an absorption maximum of $\mathrm{SbCl}_{3}$ color at $500 \mathrm{~m} \mu$ appeared in the fractions prior to the vitamin $\mathrm{D}$ fraction. This chromogen differed from vitamin D in chromatographic behaviors and color: the color produced from this chromogen was pink, while that from vitamin D orange. Resemblance of the absorption spectrum of 500 chromogen to that of vitamin D may suggest a possibility that the former is a decomposition product of vitamin $D$, 
though further investigation is necessary to clarify the point. These problems in the application of the method are the subjects for future research, since various unsaponifiable components contained in fish have not yet been clearly identified at the present stage of investigation.

In addition to these problems, it should be recalled that a minimum amount detectable of vitamin D, which is about $200 \mathrm{I}$. U. for $10 \mathrm{~g}$ of a sample in the present method, depends on such factors as the capacity of a spectrophotometer, the concentration of vitamin D in the solution to be assayed, and the thickness of the solution in the cell.

\section{SUMMARY}

Methods hitherto proposed for vitamin D determination are not applicable to separating vitamin D from the impurities contained in fish and fish products. However, a series of experiments carried out by the authors demonstrated that a combined use of clay and gradient alumina chromatography is highly efficient for the purpose.

Based on the studies on the nature of Japanese acid clay to be used for chromatography, suitable conditions and methods for activation of the clay were secured.

Satisfactory results were obtained in the experiments performed by the use of sample oils prepared from various parts of fish, dried fish and fish solubles.

\section{REFERENCES}

1. Wilkie, J.B., Jones, S.W., and Kline, O.L., J. Am. Pharm. Assor. 47, 385 (1958).

2. Baba, H., Eiyogaku Zasshi 12, 155 (1955).

3. Miwa K., Bull. Hakkaido Reg. Fish. Res. Lab. 15, 42 (1957).

4. Nield, C.H., Russel, W.C., and Zimmerli, A., J. Biol. Chem. 136, 73 (1940).

5. Emmerie, A., and Eekelen, M., Acta Brev. Neerl. 6, 133 (1936).

6. Mennier, P., and Vinet, A., Bull. Soc. Chem. Biol. 27, 186 (1945).

7. Plack, P.A., Kon, S.K., and Thompson, S.Y., Biochem. J. 7, 467 (1959).

8. Ewing, D.T., Kingsley, G.V., Brown, R.A., and Emmett, A.D., Ind. End. Chem., Anal. Ed. 15, 301 (1943).

9. DeWitt, J.B., and Sullivan, M.X., ibid. 18, 117 (1946).

10. Ewing, D.T., Powell, M.J., Brown, R.A., and Emmett, A.D., Anal. Chem. 20, 317 (1948).

11. Ewing, D.T., Schlabach, T.D., and Powell, M. J., ibid. 26, 1406 (1954).

12. Ogawa, S., and Kobayashi, T., Vitamins 19, $549(1960)$.

13. Watanabe, A., Yoshida, T., and Ochi, H., ibid. 20, 205 (1960).

14. Fujita, A., ibid. 21, 65 (1960).

15. Green, J., Biochem. J. 49, 36, 45, 54, 232, 243 (1951).

16. Numata, K., Vitamins 11, $439(1956)$.

17. Numata, K., ibid. 15, 24 (1958). 